
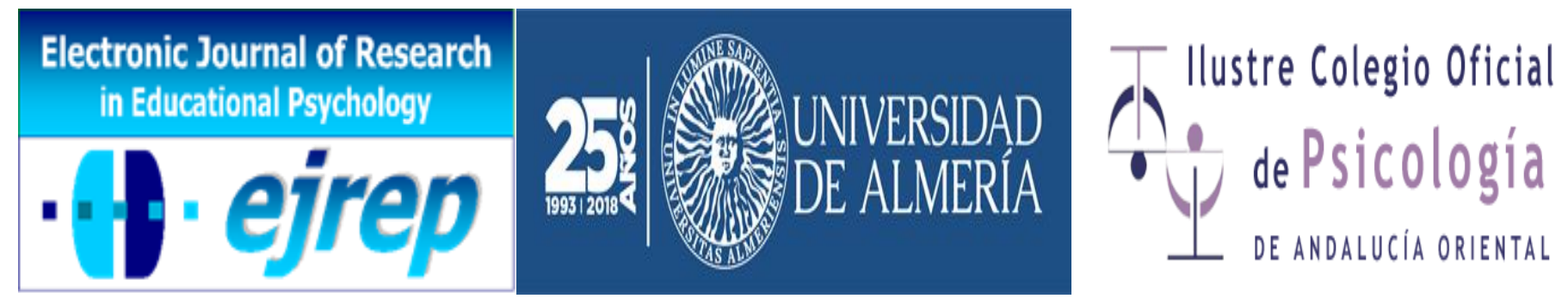

\title{
Influence of Achievement Goals and Academic Self-efficacy on Academic Achievement of Thai Undergraduate Students: Across Non Procrastinators and Procrastinators
}

\author{
Leelie Ratsameemonthon ${ }^{1}$, Robert $\mathbf{H o}^{2}$, \\ Arunya Tuicomepee ${ }^{3}$, Jon N. Blauw ${ }^{4}$
}

1. Didyasarin International College, Hatyai University, Songkhla

2. Graduate School of Psychology, Assumption University, Bangkok

3. Faculty of Psychology Chulalongkorn University, Bangkok

4 Graduate School of Psychology, Assumption University, Bangkok

\section{Thailand}

Correspondence: Leelie Ratsameemonthon. Hatyai University, 125-502 Polpichai Rd. Hatyai, Songkhla. Thailand. E-mail: leelie@hu.ac.th

(C) Universidad de Almería and Ilustre Colegio Oficial de la Psicología de Andalucía Orirental (Spain) 


\begin{abstract}
Introduction. Procrastination is a very interesting topic because even if procrastinators could anticipate the negative consequences, they still intentionally do necessary tasks with delay. This may be because some procrastinators receive positive outcomes referred to active procrastinator, but some are not called passive procrastinator. Verifying the motivational belief moderates these two different types of procrastination; therefore, this study evaluates consistency of two different configurations. Model 1 is based on achievement goal theory integrated factors between academic self-efficacy and achievement goal (achievement goals $\rightarrow$ academic self-efficacy $\rightarrow$ academic achievement). Model 3 is based on social cognitive theory of motivation separated factors between achievement goal and academic self-efficacy (academic self-efficacy, achievement goals $\rightarrow$ academic achievement) across the three groups of procrastinators (non-procrastinators, active-procrastinators, and passive procrastinators). Moreover, this study investigated the different patterns of structural relations (including both direct and indirect relationship) between the achievement goals, academic self-efficacy and academic achievement.
\end{abstract}

Method. The sample consisted of 988 Thai undergraduate students with an average age of 20 (SD = 0.99) ranging from 18 to 27 years. Structure equation model was employed to test the path model and Multi-group path analyses were used to verify differences in the path coefficients across the three types of procrastinators.

Results. The finding confirmed that with Model 1there were a higher number of significant relationships that integrated achievement goals and academic self-efficacy pertaining to academic achievement than with the Model 3 which separated achievement goal and academic self-efficacy relative to academic achievement, as well as across the three types of procrastinators.

Discussion and Conclusion. There was a substantial result of the importance of integration between academic self-efficacy and achievement goals for passive procrastinators showing in Model 1 that academic self-efficacy mediated relationships between achievement goals and academic achievement for the passive procrastinators but not the active-procrastinator or non-procrastinator groups. The implications of the findings across the three groups of procrastination are discussed.

Keywords: Procrastination, achievement goal, academic self-efficacy, academic achievement, undergraduate students 


\section{Resumen}

Introducción. La procrastinación es un tema muy interesante porque incluso cuando los procrastinadores pueden anticipar sus consecuencias negativas, estos aún retrasan intencionalmente la realización de sus tareas. Esto puede deberse a que algunos procrastinadores reciben resultados positivos concernientes a una procrastinación activa, aunque otros reciben resultados negativos a los que se les denominan procrastinadores pasivos. Para verificar la creencia motivacional entre estos dos tipos diferentes de procrastinación; este estudio evalúa la consistencia de dos configuraciones diferentes: El Modelo 1 está basado en la Teoría de Metas de Logro integrados factores como la autoeficacia académica y las metas de logro (metas de logro $\rightarrow$ autoeficacia académica $\rightarrow$ logro académico) y el Modelo 3 está basado en la teoría cognitiva social de la motivación separando factores entre la metas de logro y la autoeficacia académica (autoeficacia académica, logros académicos $\rightarrow$ logros académicos) a través de los tres grupos de procrastinadores (no procrastinadores, procrastinadores activos y procrastinadores pasivos). Además, este estudio investiga los diferentes patrones de relaciones estructurales (tanto directas como indirectas) entre las metas de logro, la autoeficacia académica y el rendimiento académico.

Método. La muestra consistie en 988 estudiantes universitarios tailandeses con un promedio de edad $(\mathrm{dt}=0,99)$ que oscila entre 18 y 27 años. Se empleó el modelo de ecuaciones de estructura para probar el modelo de ruta y se usaron análisis de trayectorias multigrupo para verificar las diferencias en los coeficientes de ruta entre los tres tipos de procrastinadores.

Resultados. El hallazgo confirmó que con el Modelo 1 hubo un mayor número de relaciones significativas que integraron las metas de rendimiento y la autoeficacia académica en relación con el rendimiento académico que con el Modelo 3 que separaba las metas de logro y la autoeficacia académica con respecto al rendimiento académico, así como a través de los tres tipos de procrastinadores.

Discusión y conclusión. Hubo un resultado sustancial en la importancia de la integración entre la autoeficacia académica y los objetivos de logro para los procrastinadores pasivos como muestra el Modelo 1 que la autoeficacia académica mediaba las relaciones entre los objetivos de logro y el rendimiento académico para los procrastinadores pasivos, pero no en los grupos de procrastinadores activo o no-procrastinadores. Se discuten las implicaciones de los hallazgos en los tres grupos de procrastinación.

Palabras clave: Procrastinación, metas de logro, autoeficacia académica, rendimiento académico, estudiantes de pregrado 


\section{Introduction}

Procrastination refers to "the act or tendency of putting things off that should be done today until tomorrow" (Schouwenburg, 1992). As a result it has been proved that it is an important factor hindering student's success in life, including academic achievement (Tice \& Baumeister, 1997; Wolters, 2004; Rice, Richardson, \& Clarks, 2012). However, there were some inconsistent results due to different types of procrastination: active and passive procratinators. Previous researches have only studied about the antecedences or consequences of different types of procrastination (Chu \& Choi, 2005; Choi \& Moran, 2009). Previous research mentioned that procrastination is not a problem of time management but it is relevant to motivational belief. This research; therefore, employed Social Cognitive Theory of Motivational (SCTM) to elaborate the motivational belief whether they have direct or indirect relationship or integrate each other across the three groups of procrastinators (active, passsive, and non procrastinator), effecting on academich achievement. Achievment goals and Expectancy value theory are underlying this SCTM. As a result, this research has proposed three models that could be constructed under the SCTM. Model 1 is based on Achievement goal theory stated that persons should have a clear goal before enhance self-efficacy to strenthen oneself to pursue difficult goal while Model 2 is based on Expectancy value theory proposed that persons should believe oneself before adopting achievement goal to assist oneself making a clearer goals. Finally, Model3: Social Cognitive theory proposed that both achievement goal and self-efficacy could motivate person to tangle with tasks directly. The three proposed models may verify the patterns of motivational belief of three types of procrastination.

\section{Types of procrastination}

Previous studies (e.g., Chu \& Choi, 2005; Choi \& Moran, 2008) found procrastinators use a "cramming" strategy to maximize their competencies to complete challenging tasks, bringing about better performance on tests compared to non-crammers (Chu \& Choi, 2005; Mendelson, 2007). Seo (2012) reported that one-day cramming or less than before the examination showed a negatively significantly on academic achievement rather than light and non-cramming. To verify this contrary outcome; Chu and Choi (2005) and Choi and Moran (2009) proposed to separate procrastinator types by means of their characteristics. 1) Passive procrastinators do not intend to procrastinate, but just do due to indecision and self-doubt of their abilities. As a result, they are more likely to experience pressure and stress by the time the deadline approaches and correlates with low academic achievement. 2) Active procrastinators are more associated with positive outcomes of procrastina- 
tion such as high academic achievement and emotional stability because their last minute pressure drives them to complete tasks with impulsive, challenging, and motivating effects (Schraw, Wadkins, \& Olafson, 2007; Chu \& Moran, 2009). While the research has found that different types of procrastination bring about different outcomes in various perspectives such as personality, cognition, and affection, they do not clarify specifically whether different types of procrastination, having different motivational beliefs, results in different academic outcomes. Studying motivational belief adopted in different types of procrastinators could help us to better understand why different types of procrastinators achieve varied academic results. Theoretical model based on Social Cognitive Theory of Motivation can be employed to illustrate why such differences exist.

\section{Social Cognitive Theory of Motivation (SCTM)}

Social Cognitive Theory of Motivation (SCTM) is one of the significant theories that could explain how students succeed in academic goal. This theory proposes that individuals possess selfbeliefs that enable them to exercise a measure of control over their thoughts, feelings and actions (Bandura, 1986). As a result, two dominant theories were proposed: Achievement Goal Theory (Ames, 1992; Elliot, 1999) and Expectancy Values Theory (Wigfield \& Eccles, 2000; Schunk \& Pajares, 2005).

\section{Achievement Goal}

Achievement Goal Theory relates to the purposes or reasons of engaging in achievement behaviors (Elliot, 1999). Mastery-approach (learning content), mastery avoidance (avoiding misunderstanding), performance-approach (demonstrating superiority), and performance-avoidance (avoiding appearing inferior; Hulleman, Schrager, Bodmann, \& Harackiewicz, 2010). As a result, the approach dichotomy is more likely associated with positive outcomes while the avoidance dichotomy is more related to negative consequences.

\section{Expectancy Values Theory}

Expectancy Values Theory involves individuals' expectations for success and the value they ascribe to succeeding are important determinants of their motivation to perform different achievement tasks (Wigfield, 1994). The motivating influence of outcome expectancy is thus partly dominated by efficacy beliefs which would induce individuals' effort and perseverance to face with difficulties. Regarding to, these two theories perspective, it could imply that both achievement goal theory and expectancy-value theory were proposed as ways that individuals could motivate their capabilities to regulate their cognition, affection, and behaviour to pursue their anticipated outcome. However, they differ in the way they conceptualize how individuals' behaviours in pursuing their goals stem from different perspectives. 
Sequential ordering of the three configurations of social cognitive theory of motivation related to academic achievement

Therefore, the previous phase of this research presented the three different configurations based on SCTM theory to identify the best fitting in academic model. The three configurations are Model 1 based on achievement goal theory which proposed that individuals; even though, have their own reasons or purposes for pursuing their goal, it is also necessary to interact with self-efficacy to sustain individuals' intention to pursue their goals. Therefore, Model 1 adopted achievement goals as the first variable and academic self-efficacy was adopted as the second variable. Model 2 based on expectancy value theory supposing that expectancy could motivate individuals to fulfill outcomes; however, it needs to interact with achievement goal in order to protect against unrealistic beliefs and to sustain motivation after receiving negative feedback. As a result, Model 2 placed academic self-efficacy as the first variable and achievement goals was posited as the second variable. Model 3 based on social cognitive theory proposing that both self-efficacy and achievement goals as personal motivation that could support these two factors relating to outcome directly, without any interaction (Bong, 2008; Kizilgunes, Tekkaya, \& Sungur, 2009). Therefore, Model 3 posited achievement goal and academic self-efficacy as the same first factors. All the three models used academic achievement as the dependent variable. The result found two models based on achievement goal theory (Model 1) and social cognitive theory of motivation (Model 3) fitted the data significantly and may convey a better pattern of relationships with academic achievement than (Model 2), which was based on expectancy-value theory. This implies that, when students realize how important goals are for them, they would strive to improve themselves in order to achieve their academic goals more efficiently and effectively than simply emphasizing expectation of outcome only. Although Model 1 and Model 3 fitted the data better than Model 2, the pattern of relationship between motivational belief and academic achievement was the same. For example, the performanceoriented goal in both approaches and the avoidance domain presented a direct relationship with academic achievement without the mediating effect of academic self-efficacy. Academic self-efficacy showed to be insignificant in relation to academic achievement; even if, it has been proposed as a factor of changing behavior. This insignificant outcome may result from analyzing participants as a whole group. Therefore, separating the three groups of procrastinators (non-procrastinator, active procrastinator, and passive procrastinator) to test the consistency measurement models (Model 1 and Model 3) may assist us to understand how different types of procrastinators and their respective goals and academic self-efficacy impacts on academic achievement. 


\section{Objectives and hypothesis}

This study was designed to investigate students who procrastinate (versus those who do not) differ in the ways their academic-self-efficacy and achievement goals impact on their academic achievement. This investigation identified: (1) the differences of motivational belief process of the academic achievement model among non-procrastinator, active procrastinator, and passive procrastinator; and (2) verify the differences in the hypothesized structural relations (both direct and indirect) between the model's exogenous (achievement goal and self-efficacy) and endogenous (academic achievement) factors.

\section{Method}

\section{Participants}

Participants comprised 988 undergraduate Business Administration and Science students attending a large enrolled three universities in Songkhla, Thailand. Their mean age was 20 (SD = 0.99), ranging from 18 to 27 years. About $76 \%$ were female and $24 \%$ were male. All sample was divided into three groups of procrastinators comprised of 409 were non-procrastinators, 377 were active procrastinators, and 202 were passive procrastinators. Non-procrastinators were separated from procrastinators by using a mean of the Passive Procrastination Scale. Non-procrastinators had a score less than the mean while procrastinators reported a score higher than the mean. The Active Procrastinator Scale was executed those who reported a score higher than the median were identified as active procrastinators while those with scores lower than the median were identified as passive procrastinators.

\section{Instruments}

Background Information Questionnaire. This researcher-constructed questionnaire consisted of two parts: (1) Personal information section designed to tap the respondent's demographic characteristics; and (2) Academic achievement section which served to indicate the student's GPA and subject grades of First Year $\left(1^{\text {st }}\right.$ and $2^{\text {nd }}$ semesters $)$.

Achievement Goal Questionnaire-Revised $(A G Q-R)$. The 12 item of AGQ-R was developed by Elliot and Murayama (2008). Participants responded on a scale of 1 (Strongly disagree) to 5 (Strongly agree). The calculated Cronbach's alpha value obtained from this study's reliability analysis was .72. Thai achievement goal questionnaire-revised has presented the same four domains of achievement goal from Western perspective which are mastery approach goal, mastery avoidance goal, performance approach goal, and performance avoidance goal. However, the reliability of Thai version found low alpha score (ranged from .62 to .72) and from English version (.84 to .94). This 
may be because of the theory derived from Western concept. Moreover, Elliot and Murayama (2008) mentioned that mastery avoidance goal showing a combination of positive and negative contents so it may cause the confusion while do the translation.

Academic Self-Efficacy Scale. This 79-item was adapted from a Thai questionnaire developed by Ngamsiri (1997). Respondents were asked to rate themselves using a 10-Likert-type scale from 0 (Uncertain) to 9 (Extremely certain). The calculated Cronbach's alpha value obtained from this study's reliability analysis was .98 .

Passive Procrastination Scale and Active Procrastination Scale. The 6-item of Passive Procrastination Scale and the 16-item of Active Procrastination Scale were developed by Chu and Choi (2005). Regarding the cultural perspective e.g., active procrastinator scale is more applicable for the people quite tolerant of slowness or lack of punctuality (Choi \& Moran, 2009). Participants were asked to rate themselves on a scale of 1 (Not at all true) to 7 (Very true). Two scales was calculated Cronbach's alpha value to obtain reliability analysis from this study were .82 for Passive Procrastination Scale and .80 for Active Procrastination Scale.

\section{Procedure}

To increase the intruments validity, the three instruments (achievement goal questionnaire, passive procrastination scale and active procrastination scale) were translated and back-translated by two independent bilingual experts. Self-efficacy questionnaire Thai version including the three translated questionnaires were then examined on second year students. Participants were debriefed as to the purpose of the study and confidentiality.

\section{Data analysis}

Structure equation modeling was employed to test the path model. The analysis starts with select the measurement items to represent latent constructs.

\section{Results}


Table 1. A synthesis table of the results

\begin{tabular}{|c|c|c|}
\hline Stage & Purposes & Result \\
\hline $\begin{array}{l}\text { Stage } 1 \text { Selection of measu- } \\
\text { rement items to represent } \\
\text { latent constructs }\end{array}$ & $\begin{array}{l}\text { Identify the measurement } \\
\text { model representing the latent } \\
\text { variables }\end{array}$ & $\begin{array}{l}\text { Four latent variables of achievement } \\
\text { goals consist of mastery-approach, } \\
\text { mastery avoidance, performance } \\
\text { approach, and performance } \\
\text { avoidance. Academic Self-efficacy } \\
\text { is presented by one latent variable } \\
\text { (Figure 1). }\end{array}$ \\
\hline $\begin{array}{l}\text { Stage } 2 \text { Multi-group confir- } \\
\text { mation factor-analysis: Eva- } \\
\text { luation of the consistency of } \\
\text { the measurement model } \\
\text { across the three group of pro- } \\
\text { crastinators. }\end{array}$ & $\begin{array}{l}\text { 1. Verify } 22 \text { measurement } \\
\text { items reflecting six latent } \\
\text { constructs consisting of } \\
\text { achievement goal comprising } \\
\text { of four latent constructs each } \\
\text { construct having three measu- } \\
\text { rement items, academic self- } \\
\text { efficacy having one latent } \\
\text { construct consisting six } \\
\text { measurement items, and aca- } \\
\text { demic achievement compo- } \\
\text { sing of one latent construct } \\
\text { comprising of four measure- } \\
\text { ment items. } \\
2 . \text { Test the items' factor } \\
\text { loading are similar or diffe- } \\
\text { rent across the three groups of } \\
\text { procrastinators. }\end{array}$ & $\begin{array}{l}\text { 1. The variant model consisting } 22 \\
\text { measurement items reflect six latent } \\
\text { construct fitted data well. (Figure 1) } \\
\text { 2. This variant model fitted data } \\
\text { well across the three types of pro- } \\
\text { crastinators } \\
\text { 3. The standardize regression coef- } \\
\text { ficients (factor loading) for the } \\
\text { measurement variables of each type } \\
\text { of procrastinator could be explained } \\
\text { as follows. For non- } \\
\text { procrastinators could be explained } \\
\text { by thinking of academic self- } \\
\text { efficacy } 88 \% \text { to } 27 \% \text { of mastery } \\
\text { avoidance of achievement goals, } \\
\text { active-procrastinator could be } \\
\text { explained by } 86 \% \text { of GPA2 to } 24 \% \\
\text { of mastery avoidance goal of achie- } \\
\text { vement goals, and passive procras- } \\
\text { tinator could be explained by } 89 \% \\
\text { of GPA2 to } 20 \% \text { of mastery } \\
\text { avoidance goal of achievement } \\
\text { goals. (Table } 2 \text { ) }\end{array}$ \\
\hline $\begin{array}{l}\text { Stage 3: Multi-group path } \\
\text { analysis: Evaluation of the } \\
\text { consistency of the academic } \\
\text { achievement Model } 1 \text { (inte- } \\
\text { grated achievement goal and } \\
\text { academic self-efficacy) in- } \\
\text { fluence on academic achie- } \\
\text { vement across the three types } \\
\text { of procrastinators }\end{array}$ & $\begin{array}{l}\text { To identify whether Model } 1 \\
\text { presents the same dynamic } \\
\text { across the three groups or not. }\end{array}$ & $\begin{array}{l}\text { Model } 1 \text { has fitted the data signifi- } \\
\text { cantly. The structural relationship } \\
\text { presented differently when conside- } \\
\text { ring academic achievement across } \\
\text { the three types of procrastinators. } \\
\text { Passive procrastinators reported } \\
\text { more significant path coefficients } \\
\text { than the other two types of procras- } \\
\text { tinators. Passive procrastinator } \\
\text { adopting mastery-approach goals } \\
\text { and performance-avoidance goals } \\
\text { has both direct and indirect rela- } \\
\text { tionships with academic achieve- } \\
\text { ment. Specifically, the more they } \\
\text { adopt mastery-approach goals and }\end{array}$ \\
\hline
\end{tabular}




\begin{tabular}{|c|c|c|}
\hline Stage & Purposes & Result \\
\hline & & $\begin{array}{l}\text { performance-avoidance goals, the lo- } \\
\text { wer their reported level of academic } \\
\text { achievement. Also, the more they adopt } \\
\text { mastery-approach goals and perfor- } \\
\text { mance-avoidance goals, the higher } \\
\text { their perceived level of academic self- } \\
\text { efficacy, the higher their reported level } \\
\text { of academic achievement. } \\
\text { Active procrastinators, their adoption } \\
\text { of mastery-approach goals, performan- } \\
\text { ce-approach goals, and performance- } \\
\text { avoidance goals was found to be direc- } \\
\text { tly related to academic achievement. } \\
\text { Thus, the higher their adoption of mas- } \\
\text { tery-approach goals and performance- } \\
\text { avoidance goals, the lower their repor- } \\
\text { ted level of academic achievement. The } \\
\text { higher their adoption of performance- } \\
\text { approach goals, the higher their repor- } \\
\text { ted level of academic achievement. } \\
\text { Non-procrastinators, their adoption of } \\
\text { mastery-avoidance goals, performance- } \\
\text { approach goals, and performance- } \\
\text { avoidance goals was found to be direc- } \\
\text { tly related to academic achievement. } \\
\text { Thus, the higher their adoption of mas- } \\
\text { tery-avoidance goals and performance- } \\
\text { approach goals, the higher their repor- } \\
\text { ted level of academic achievement. } \\
\text { The higher their adoption of perfor- } \\
\text { mance-avoidance goals, the lower their } \\
\text { reported level of academic achieve- } \\
\text { ment. (Table } 3 \text {, Figure } 2 \text { ) }\end{array}$ \\
\hline $\begin{array}{l}\text { Stage 4: Multi-group path } \\
\text { analysis: Evaluation of the } \\
\text { consistency of the academic } \\
\text { achievement Model } 3 \text { (separa- } \\
\text { ted achievement goal and } \\
\text { academic self-efficacy) in- } \\
\text { fluences on academic achie- } \\
\text { vement across the three types } \\
\text { of procrastinators. }\end{array}$ & $\begin{array}{l}\text { To identify whether Model } 3 \\
\text { presents the same dynamic } \\
\text { across the three groups or not }\end{array}$ & $\begin{array}{l}\text { Model } 3 \text { has fitted the data significantly } \\
\text { and supported the structure of model } \\
\text { across the three types of procrastina- } \\
\text { tors. However, there was only direct } \\
\text { significantly relationship between } \\
\text { achievement goals particularly perfor- } \\
\text { mance-approach goals and performan- } \\
\text { ce-avoidance goals and level of acade- } \\
\text { mic achievement across the three types } \\
\text { of procrastinators. (1) The more they } \\
\text { adopted performance-approach goals, } \\
\text { the higher their level of academic } \\
\text { achievement and (2) the more they } \\
\text { adopted performance-avoidance goals, } \\
\text { the lower their level of academic } \\
\text { achievement (Table 4, Figure 3). }\end{array}$ \\
\hline
\end{tabular}




\section{Stage 1: Selection of measurement items to represent latent constructs}

First, the latent factors of achievement goal Thai version were represented by the four measurements which was similar to the four-factor structure of the original Western version developed by Elliot and Murayama (2008). The four measures are mastery approach goal, mastery avoidance goal, performance approach goal, and performance avoidance goal. Second, based on Ngamsiri (1997) the latent factor of Academic self-efficacy consisted of learning, thinking, calculating, performing an exam, reading, and writing. However, the six latent constructs of 'academic self-efficacy' were treated as a single construct in this research. This is because the six latent constructs could not be executed the structural equation model.

Stage 2: multi-group confirmatory factor analysis: evaluation of the consistency of the measurement model across the three groups of procrastinators (non-procrastinators, active procrastinators, and passive procrastinators)

Before evaluating the fit of the two path models; model 1 based on achievement goal theory and model 3 based on social cognitive theory of motivation, it was necessary to (1) verify that the 22 measurement items written to reflect the six latent constructs of achievement goals (masteryapproach (3-item), mastery-avoidance (3-item), performance-approach (3-item), performanceavoidance (3-item)), academic self-efficacy (6-item), and academic achievement (4-item) did so in a statistically reliable manner, and (2) test whether the items' factor loadings (regression weights) are similar (invariant) or different (variant) across the three groups of procrastinators. Figure 1 presents the measurement model (for the three groups of procrastinators: non-procrastinators, activeprocrastinators, and passive procrastinators), with the six latent variables and their respective measurement indicators. For this model, all factor loadings were freed, items were allowed to load on only one factor, and the five factors were allowed to correlate.

Multi-group confirmatory factor analysis (CFA), via structural equation modeling, was employed to determine the consistency of the measurement model across the three groups of procrastinators (non-procrastinators, active procrastinators, and passive procrastinators). The following sequence of hypotheses was developed to explore differences between the groups' measurement models: (a) The models have the same form (i.e., the same pattern of fixed and free parameters); (b) the factor loadings are identical (invariant) across groups. In determining the consistency of the model across these three groups, the model was first specified to have the same pattern of fixed and free parameters for the three groups, but allowed these parameters to be estimated separately within each group. 
Results indicated that this unconstrained (variant) model fitted the data well. Although the overall chi-square value was significant, $\chi^{2}(d f=582)=1503.36, p<.001$, the incremental fit indices (Normed Fit Index - NFI, Incremental Fit Index - IFI, Tucker-Lewis Index - TLI, Comparative Fit Index - CFI) are close to or above 0.90 (range: $0.87-0.92$ ). The RMSEA value of 0.04 is also within the range suggested by Browne and Cudeck (1993) and indicates that the model fits the population covariance matrix very well. These fit indices indicated that the model provided a good fit relative to a null or independence model, and support the hypothesized structure of the model posited for the three groups of respondents.

The preceding model specified the same pattern of fixed and free parameters for the three groups of respondents, but estimated these parameters separately within each group. The next series of analyses involved constraining the factor loadings to be invariant for the three groups. Results from the analysis indicated that this constrained model also fitted the data well. Although the overall chi-square was significant, $\chi^{2}(d f=614)=1528.86, p<.001$, the incremental fit indices (NFI, IFI, TLI, CFI) are close to or above 0.90 (range: $0.87-0.92$ ). The RMSEA value of 0.04 (similar to the variant model) is also within the range suggested by Browne and Cudeck (1993) and indicates that this invariant model also fits the population covariance matrix very well. The AIC index could be also used to further compare the fit of the two models. The AIC measure for the invariant model (1818.86) is lower than that of the variant model (1857.36), indicating that the invariant model is more parsimonious and better fitting than the variant model. Although the AIC index indicated that the constrained (invariant) model fitted the data set better than the unconstrained (variant) model, it was still necessary to test whether there are significant differences in the items' factor loadings for the three groups of procrastinators. This was done via the calculation of critical ratios for pair-wise differences among all factor loadings in the model. The critical ratio for a pair of estimates (C.R. < $\pm 1.96, p<.001$ ) provides a test of the hypothesis that the two parameters are equal (Arbuckle \& Wothke, 1999). The results showed significant group differences between active procrastinators and passive procrastinators for the factor loadings associated with the academic achievement item of p16. This difference in factor loadings was incorporated in the analysis of the structural path model.

The standardized regression weights, residuals, and explained variances for the measurement items representing the factors of achievement goals (mastery-approach goal, mastery-avoidance goal, performance-approach goal, performance-avoidance goal), academic self-efficacy, and academic achievement for the three types of procrastinators are presented in Table 2 
The standardized regression coefficients (factor loadings) for the measurement variables were all positive and significant by the critical ratio test, $p<.05$. Standardized loadings ranged from 0.51 to 0.91 for non-procrastinator participants, from 0.49 to 0.93 for active procrastinator participants, and from 0.45 to 0.94 for passive procrastinator participants. These values indicated that the indicator variables hypothesized to represent their respective latent constructs did so in a reasonable manner. For the non-procrastinators, the percentage of residual (unexplained) variances for the 22 measurement variables ranged from $12 \%$ (i.e., $88 \%$ of the variance explained) (thinking) to $73 \%$ (i.e., 27\% of the variance explained) (AGQ11). For the active procrastinators, the percentage of residual (unexplained) variances for the 22 measurement variables ranged from $14 \%$ (i.e., $86 \%$ of the variance explained) (GPA2) to $76 \%$ (i.e., $24 \%$ of the variance explained) (AGQ11). For the passive procrastinators, the percentage of residual (unexplained) variances for the 22 measurement variables ranged from $11 \%$ (i.e., $89 \%$ of the variance explained) (GPA2) to $80 \%$ (i.e., $20 \%$ of the variance explained) (AGQ11).

Table 2. Standardized Regression Weights, Residuals, and Explained Variances for the Factors of Achievement Goals, Academic Self-efficacy, and Academic Achievement for the Three Types of Procrastinators

\begin{tabular}{|c|c|c|c|c|c|c|c|c|c|c|c|}
\hline \multicolumn{3}{|l|}{ Parameter } & \multicolumn{3}{|c|}{$\begin{array}{c}\text { Standardized } \\
\text { Regression Weight }\end{array}$} & \multicolumn{3}{|c|}{$\begin{array}{l}\text { Residual } \\
\text { Variance }\end{array}$} & \multicolumn{3}{|c|}{$\begin{array}{l}\text { Explained } \\
\text { Variance }\end{array}$} \\
\hline & & & Proc & Proc & Proc & Proc & Proc & Proc & Proc & Proc & Proc \\
\hline \multirow{3}{*}{\multicolumn{2}{|c|}{ Mapproach $\rightarrow$}} & AGQ7 & .66 & .62 & .64 & .57 & .62 & .59 & .43 & .38 & .41 \\
\hline & & AGQ1 & .67 & .64 & .67 & .56 & .59 & .55 & .44 & .41 & .45 \\
\hline & & AGQ3 & .76 & .72 & .72 & .43 & .48 & .48 & .57 & .52 & .52 \\
\hline \multirow[t]{3}{*}{ Mavoid } & $\rightarrow$ & AGQ11 & .51 & .49 & .45 & .73 & .76 & .80 & .27 & .24 & .20 \\
\hline & & AGQ9 & .71 & .68 & .60 & .49 & .54 & .64 & .51 & .46 & .36 \\
\hline & & AGQ5 & .67 & .65 & .56 & .55 & .58 & .69 & .45 & .42 & .31 \\
\hline \multirow[t]{3}{*}{ Papproach - } & $\rightarrow$ & AGQ8 & .60 & .50 & .53 & .64 & .75 & .72 & .36 & .25 & .28 \\
\hline & & AGQ2 & .70 & .59 & .59 & .51 & .65 & .66 & .49 & .35 & .34 \\
\hline & & AGQ4 & .75 & .65 & .67 & .43 & .58 & .55 & .57 & .42 & .45 \\
\hline \multirow[t]{3}{*}{ Pavoid } & $\rightarrow$ & AGQ6 & .62 & .57 & .59 & .61 & .68 & .66 & .39 & .32 & .34 \\
\hline & & AGQ10 & .68 & .65 & .64 & .54 & .58 & .60 & .46 & .42 & .40 \\
\hline & & AGQ12 & .73 & .67 & .64 & .46 & .55 & .59 & .54 & .45 & .41 \\
\hline \multirow[t]{6}{*}{ ASE } & $\rightarrow$ & Calculate & .70 & .62 & .57 & .51 & .62 & .67 & .49 & .38 & .33 \\
\hline & & Thinking & .94 & .90 & .91 & .12 & .18 & .17 & .88 & .82 & .83 \\
\hline & & Learning & .90 & .89 & .84 & .19 & .20 & .29 & .81 & .80 & .71 \\
\hline & & Exam & .75 & .71 & .68 & .43 & .49 & .54 & .57 & .51 & .46 \\
\hline & & Reading & .87 & .84 & .83 & .24 & .30 & .32 & .76 & .70 & .68 \\
\hline & & Writing & .91 & .85 & .84 & .18 & .27 & .29 & .82 & .73 & .71 \\
\hline \multirow[t]{4}{*}{ AA } & $\rightarrow$ & Grade 1 & .83 & .80 & .80 & .31 & .36 & .36 & .69 & .64 & .64 \\
\hline & & Grade 2 & .85 & .80 & .85 & .28 & .37 & .27 & .72 & .63 & .73 \\
\hline & & GPA 1 & .88 & .91 & .89 & .23 & .18 & .21 & .77 & .82 & .79 \\
\hline & & GPA 2 & .91 & .93 & .94 & .17 & .14 & .11 & .83 & .86 & .89 \\
\hline
\end{tabular}

ASE $=$ Academic self-efficacy

$\mathrm{AA}=$ Academic achievement 


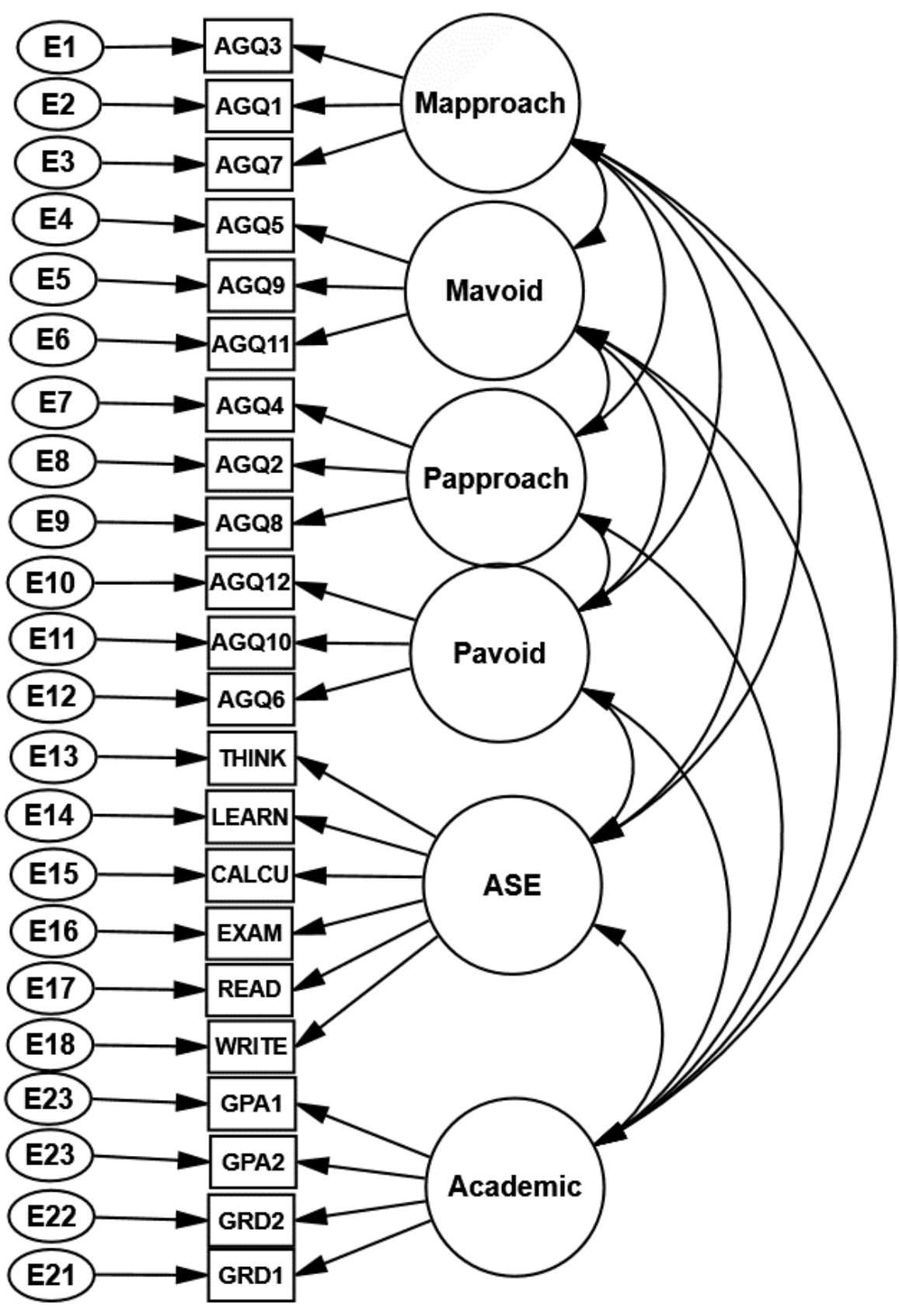

Figure 1. Measurement model representing the latent variables of mastery-approach goal, mastery-avoidance goal, performance-approach goal, performance-avoidance goal, academic selfefficacy, and academic achievement. 
Stage 3: Multi-group path analysis: Evaluation of the consistency of the academic achievement Model 1 (achievement goals $\rightarrow$ academic self-efficacy $\rightarrow$ academic achievement) across the three groups of procrastinators (non-procrastinators, active-procrastinators, and passive procrastinators)

Results from the multi-model path analysis of the previous study showed that the process by which academic achievement is impacted on by academic self-efficacy and achievement goals, both directly and indirectly, is best represented by the pattern of structural relationships hypothesized for Model 1 and Model 3 than for Model 2. As such, both Models 1 and 3 will be retained for further analysis in this study.

The present multi-group path analysis was conducted for Model 1 to determine whether or not the hypothesized pattern of structural relationships (achievement goals $\rightarrow$ academic selfefficacy $\rightarrow$ academic achievement) followed the same dynamics for the three types of procrastinators. That is, the analysis was conducted to determine the extent to which the posited model was consistent across the three groups.

Based on the findings from the confirmatory factor analysis, the factor loading associated with the academic achievement item of p16 was freed, i.e., it was to be estimated separately within each group, while the other 21 factor loadings were fixed to be invariant across groups. The following sequence of hypotheses was developed for analyzing group differences in this model: (1) path coefficients have the same pattern for the three types of procrastinators; and (2) path coefficients are identical for the three types of procrastinators. In determining the consistency of the model across the types of procrastinators, the model was first specified to have the same pattern of path coefficients for all three groups, but allowed the coefficients to be estimated separately within each group. For this variant model, $\chi^{2}(d f=616, N=988)=1924.48, p<.001$. The incremental fit indices (NFI, IFI, TLI, CFI) were close to 0.90 (range: $0.83-0.88$ ). These fit indices indicated that the posited model provided a fairly good fit relative to the null or independent model, and supported the hypothesized structure of the model posited for the three groups of procrastinators.

The preceding model specified the same pattern of fixed and free parameters for the three groups of procrastinators, but estimated these parameters separately within each group. In order to test the consistency of the model across the three groups, the model was respecified to have the path coefficients constrained to be invariant across the three groups of procrastinators. Results from the analysis indicated that this invariant model fitted the data fairly well, $\chi^{2}(d f=634, N=988)=$ 
1997.30, $p<.001$; the incremental fit indices of (NFI, IFI, TLI, CFI) were close to 0.90 (ranged from 0.83 - 0.88). Results of a chi-square difference test comparing this model with one that simply specified the same pattern of path coefficients indicated that the variant model fitted the data significantly better, $\chi^{2}(d f=18, N=988)=72.82, p<.001$. This suggests that some of the structural relationships represented in the path model are significantly different when considering academic achievement by non-procrastinators, active procrastinators, and passive procrastinators.

The goodness-of-fit of competing models can also be compared by means of the Akaike information criterion (AIC) measure (Akaike, 1987). In evaluating hypothesized models, this measure takes into account both model parsimony (i.e., achieving a higher degree of fit per degree of freedom used) and model fit. Simple models that fit well receive low scores, whereas poorly fitting models get high scores. Comparing the AIC measures for the invariant model and the variant model, it is evident that the AIC for the variant model (2210.48) is lower than that for the invariant model (2247.30), indicating that the variant model is more parsimonious and better fitting than the invariant model. Table 3 presents the goodness-of-fit indices for both these models, together with the model comparison statistics.

Table 3 Chi-Square Goodness-of-fit Values, Incremental Fit Indices (NFI, IFI, TLI, CFI), Akaike Information Criterion (AIC), and Model Comparison (Model 1)

\begin{tabular}{lcccccccc}
\hline \multicolumn{1}{c}{ Model } & $\begin{array}{c}\chi^{2} \\
(N=998)\end{array}$ & $d f$ & $P$ & NFI & IFI & TLI & CFI & AIC \\
\hline Null Model & 11593.39 & 693 & $<.001$ & 0.00 & 0.00 & 0.00 & 0.00 & 11725.39 \\
$\begin{array}{l}\text { Model A } \\
\text { (Variant) Model }\end{array}$ & 1924.48 & 616 & $<.001$ & 0.83 & 0.88 & 0.87 & 0.88 & 2210.48 \\
$\begin{array}{l}\text { Model B } \\
\text { (Invariant) Model }\end{array}$ & 1997.30 & 634 & $<.001$ & 0.83 & 0.88 & 0.86 & 0.88 & 2247.30 \\
$\begin{array}{l}\text { Model comparison } \\
\text { Model A vs Model B }\end{array}$ & 72.82 & 18 & $<.001$ & 0.00 & 0.00 & 0.01 & 0.00 & 36.82 \\
\hline
\end{tabular}

\section{Standardized regression path for non-procrastinators}

As shown in Fig. 2 for non-procrastinators, their achievement goals of mastery-avoidance goals, performance-approach goals, and performance-avoidance goals were found to be directly related to the criterion variable of academic achievement. Thus, the higher their adoption of mastery-avoidance and performance-approach goals, the higher their reported level of academic achievement $(\beta=0.89$ and $\beta=0.82$ respectively). The results also showed that the higher their adoption of performance-avoidance goals, the lower their reported level of academic achievement $(\beta=-0.27)$. None of the exogenous achievement goals were found to be related indirectly (being mediated by 
perceived academic self-efficacy) to the criterion variable of academic achievement $(p>.05)$. Nevertheless, the adoption of mastery-approach goals was found to be positively and significantly related to the mediator of perceived academic self-efficacy. Thus, the higher the non-procrastinators adoption of mastery-approach goals, the higher their reported level of academic achievement $(\beta=$ $0.57)$.

\section{Standardized regression path for active procrastinators}

As shown in Fig. 2, for active procrastinators, their achievement goals of mastery-approach goals, performance-approach goals, and performance-avoidance goals were found to be directly related to the criterion variable of academic achievement. Thus, the higher their adoption of mastery-approach and performance-avoidance goals, the lower their reported level of academic achievement ( $\beta=-0.52$ and $\beta=-0.53$ respectively). The results also showed that the higher their adoption of performance-approach goals, the higher their reported level of academic achievement $(\beta=0.60)$. None of the exogenous achievement goals were found to be related indirectly (being mediated by perceived academic self-efficacy) to the criterion variable of academic achievement $(p>.05)$.

\section{Standardized regression path for passive procrastinators}

As shown in Fig. 2. for passive procrastinators, their achievement goals of mastery-approach goals and performance-avoidance goals were found to be directly and indirectly related to the criterion variable of academic achievement. Thus, the higher their adoption of mastery-approach and performance-avoidance goals, the lower their reported level of academic achievement $(\beta=-0.70$ and $\beta=-0.67$ respectively). Also, the higher their adoption of mastery- approach and performanceavoidance goals, the higher their perceived academic self-efficacy $\quad(\beta=0.34$ and $\beta=0.56$ respectively); the higher their perceived academic self-efficacy, the higher their reported level of academic achievement $(\beta=0.64)$. The results also showed that for passive procrastinators, their achievement goals of mastery-avoidance goals were found to be indirectly related to the criterion variable of academic achievement. Thus, the lower their adoption of mastery-avoidance goals, the higher their perceived academic self-efficacy $(\beta=-0.47)$; the higher their perceived academic self-efficacy, the higher their reported level of academic achievement $(\beta=0.64)$. 


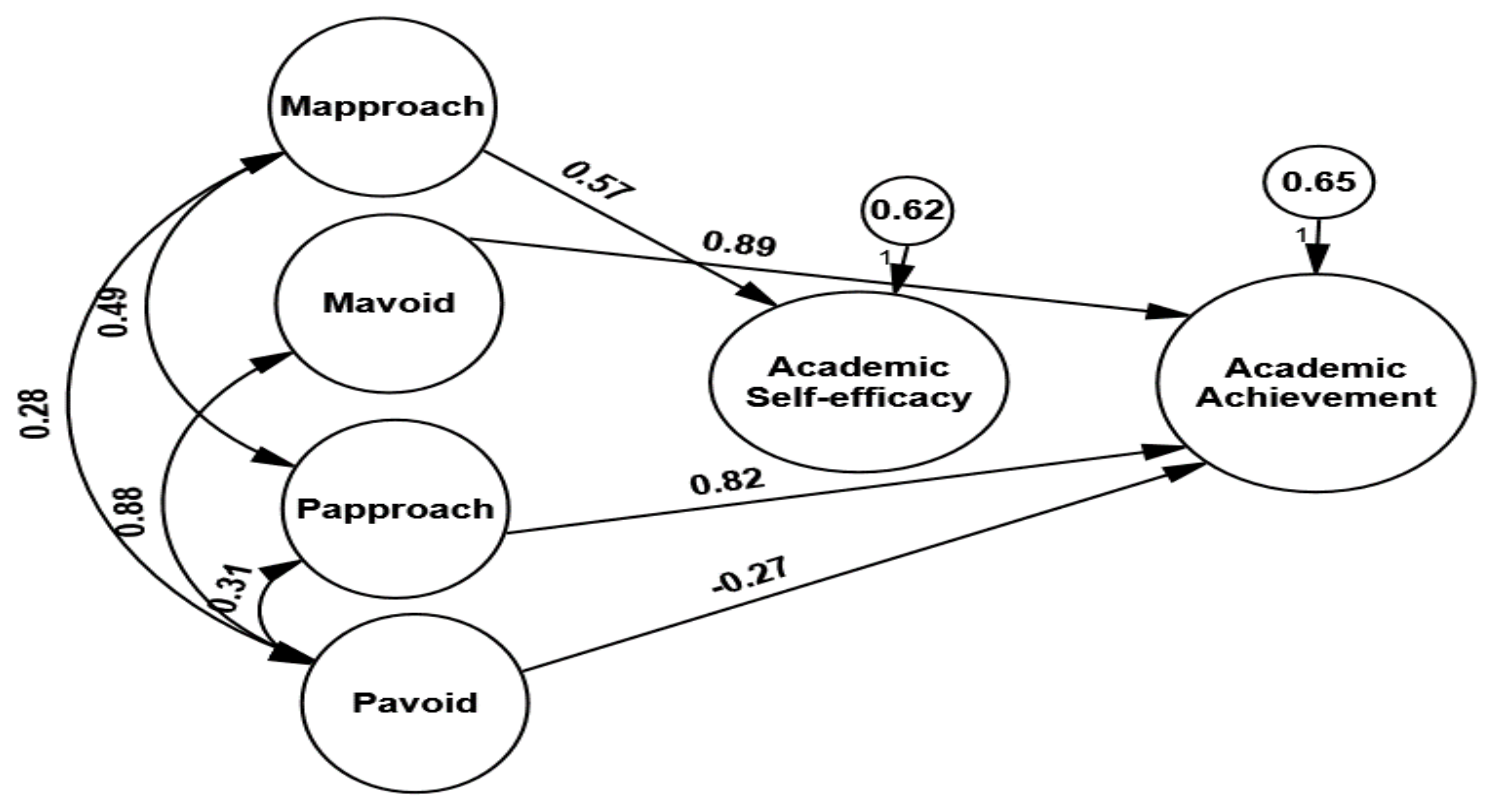

Non-Procrastination

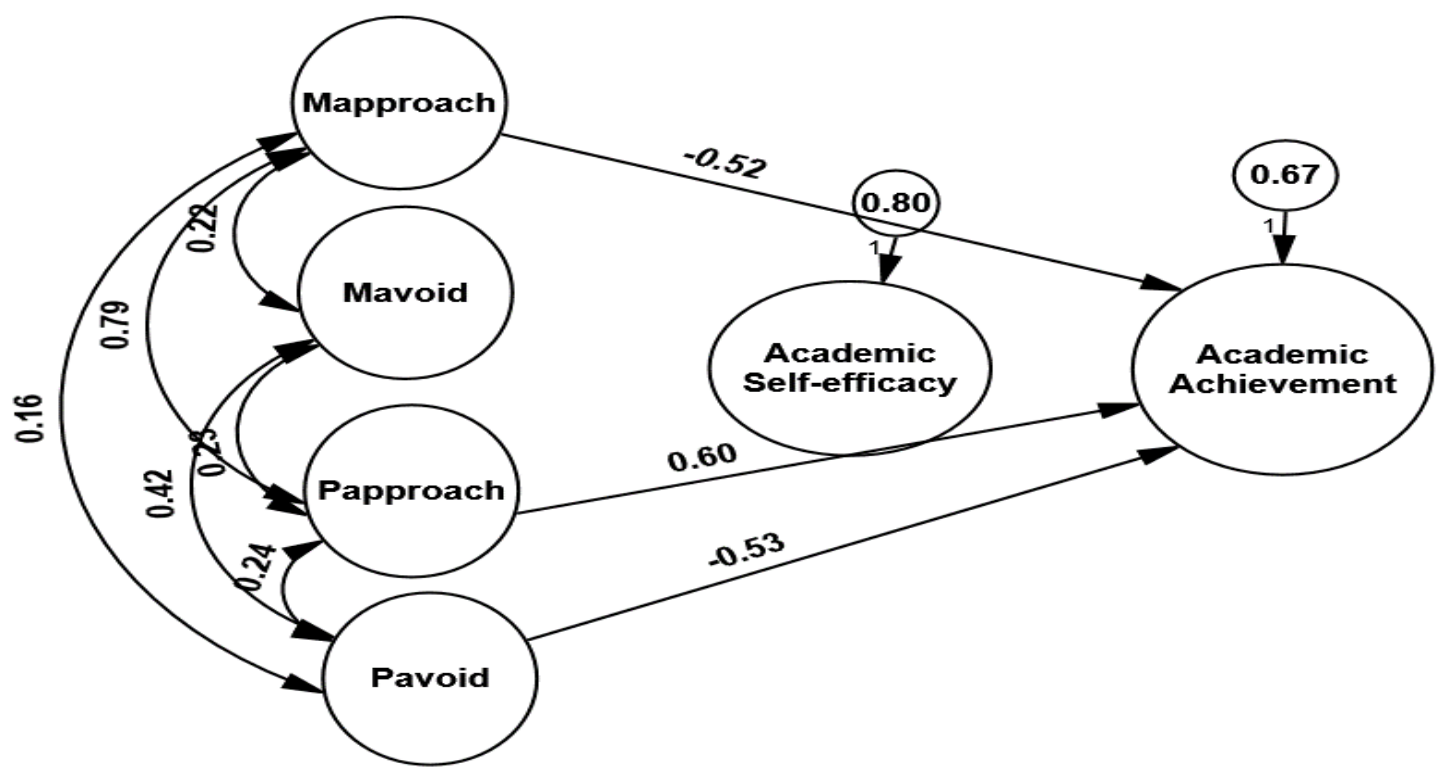




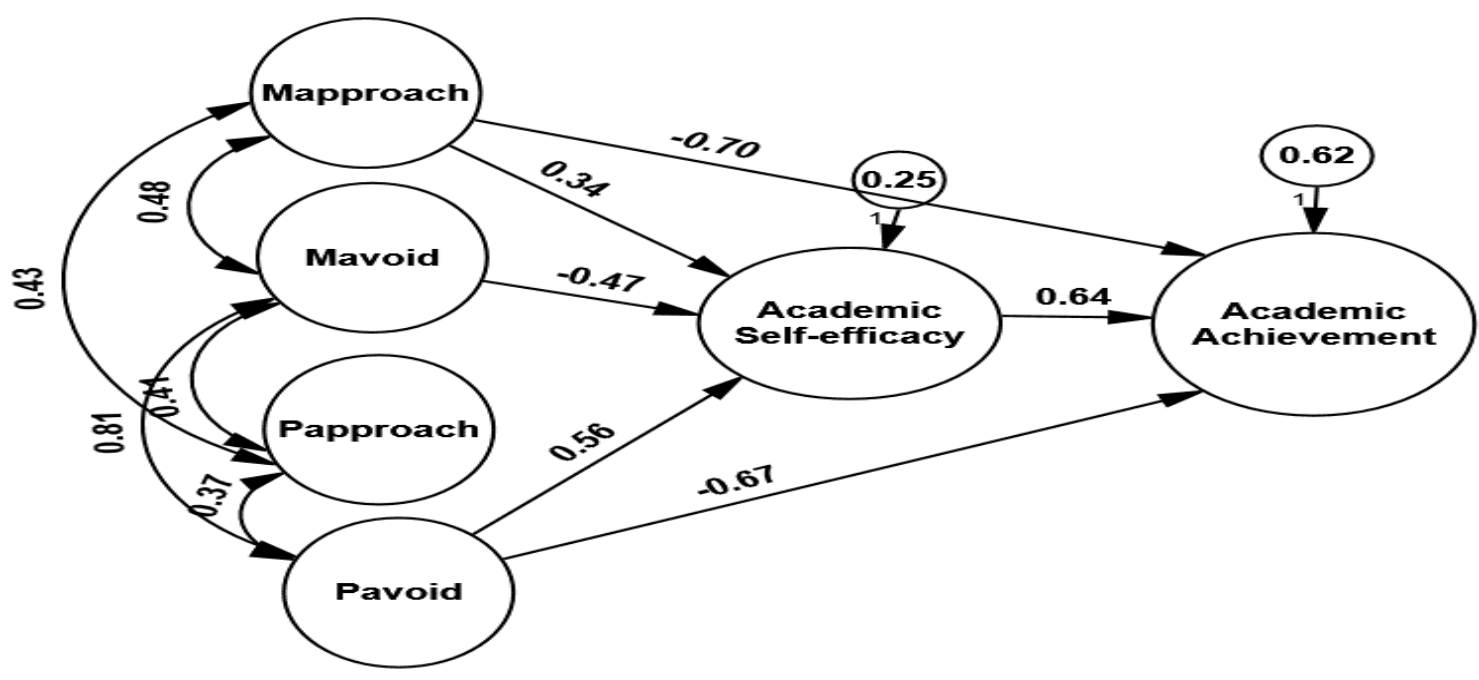

\section{Passive-Procrastination}

Figure 2. Academic achievement path model (Model 1) for the three types of procrastinators together with the model's significant path coefficients

\section{Summary of standardized regression path coefficients}

From Table 4 it can be seen that passive procrastinators reported the most number of significant path coefficients for the posited model. For this type of procrastinators, their adoption of mastery-approach goals and performance-avoidance goals has both direct and indirect relationships with the criterion variable of academic achievement. Specifically, the more they adopt mastery-approach goals and performance-avoidance goals, the lower their reported level of academic achievement $(\beta=$ -0.70 and $\beta=-0.67$ respectively). Also, the more they adopt mastery-approach goals and performance-avoidance goals, the higher their perceived level of academic self-efficacy $(\beta=0.34$ and $\beta=0.56$ respectively); the higher their perceived level of academic self-efficacy, the higher their reported level of academic achievement $(\beta=0.64)$. For active procrastinators, their adoption of masteryapproach goals, performance-approach goals, and performance-avoidance goals was found to be directly related to the criterion variable of academic achievement. Thus, the higher their adoption of 
mastery-approach goals and performance-avoidance goals, the lower their reported level of academic achievement ( $\beta=-0.52$ and $\beta=-0.53$ respectively). The higher their adoption of performanceapproach goals, the higher their reported level of academic achievement $(\beta=0.60)$. For nonprocrastinators, their adoption of mastery-avoidance goals, performance-approach goals, and performance-avoidance goals was found to be directly related to the criterion variable of academic achievement. Thus, the higher their adoption of mastery-avoidance goals and performance-approach goals, the higher their reported level of academic achievement ( $\beta=0.89$ and $\beta=0.82$ respectively). The higher their adoption of performance-avoidance goals, the lower their reported level of academic achievement $(\beta=-0.27)$.

Table 4. Summary of the Significant Path Coefficients Across the Three Types of Procrastinators (Model 1)

\begin{tabular}{lccc}
\hline & \multicolumn{3}{c}{ Path coefficients } \\
\cline { 2 - 4 } Parameter & $\begin{array}{c}\text { Non } \\
\text { Procrastinators }\end{array}$ & $\begin{array}{c}\text { Active } \\
\text { Procrastinators }\end{array}$ & $\begin{array}{c}\text { Passive } \\
\text { Procrastinators }\end{array}$ \\
\hline Mapproach $\rightarrow$ Academic self-efficacy & 0.57 & & 0.34 \\
Mavoid $\rightarrow$ Academic self-efficacy & & & -0.47 \\
Pavoid $\rightarrow$ Academic self-efficacy & & & 0.56 \\
Mapproach $\rightarrow$ Academic achievement & & -0.52 & -0.70 \\
Mavoid $\rightarrow$ Academic achievement & 0.89 & & \\
Papproach $\rightarrow$ Academic achievement & 0.82 & 0.60 & -0.67 \\
Pavoid $\rightarrow$ Academic achievement & -0.27 & -0.53 & \\
\hline
\end{tabular}

Step 4: Multi-group path analysis: Evaluation of the consistency of the academic achievement Model 3 (academic self-efficacy, achievement goals $\rightarrow$ academic achievement) across the three groups of procrastinators (non-procrastinators, active-procrastinators, and passive procrastinators)

The previous multi-group path analysis was conducted for Model 1. The present multi-group path analysis was conducted on Model 3 to determine whether or not the hypothesized pattern of structural relationships (academic self-efficacy, achievement goals $\rightarrow$ academic achievement) followed the same dynamics for the three types of procrastinators. That is, the analysis was conducted to determine the extent to which the posited model was consistent across the three groups. Based on the findings from the confirmatory factor analysis, the factor loading associated with the academic achievement item of p16 was freed, i.e., it was to be estimated separately within each group, while the other 21 factor loadings were fixed to be invariant across groups. The following sequence of hypotheses was developed for analyzing group differences in this model: (1) path coefficients have the same pattern for the three types of procrastinators; and (2) path coefficients are identical for the 
three types of procrastinators. In determining the consistency of the model across the three types of procrastinators, the model was first specified to have the same pattern of path coefficients for all three groups, but that these coefficients were allowed to be estimated separately within each group. For this variant model, $\chi^{2}(d f=612, N=988)=1521.56, p<.001$. The incremental fit indices (NFI, IFI, TLI, CFI) are close to and above 0.90 (range: $0.87-0.92$ ). These fit indices indicated that the posited model provided a reasonably good fit relative to the null or independent model, and supported the hypothesized structure of the model across the three types of procrastinators.

The preceding model specified the same pattern of fixed and free parameters for the three groups of procrastinators, but estimated these parameters separately within each group. In order to test the consistency of the model across the three groups, the model was respecified to have the path coefficients constrained to be invariant across the three groups. Results from the analysis indicated that this invariant model also fitted the data reasonably well, $\chi^{2}(d f=622, N=988)=1537.18$, $p<.001$; the incremental fit indices (NFI, IFI, TLI, CFI) were close to and above 0.90 (ranged from 0.87 - 0.92). Results of a chi-square difference test comparing this model with one that simply specified the same pattern of path coefficients indicated that the variant model fitted the data significantly better, $\chi^{2}(d f=10, N=988)=15.62, p<.001$. This suggests that some of the structural relationships represented in the path model are significantly different in relation to academic achievement across non-procrastinators, active procrastinators, and passive procrastinators.

The goodness-of-fit of competing models can also be compared by the Akaike information criterion (AIC) measure. Simple models that fit well receive low scores, whereas poorly fitting models get high scores. Comparing the AIC measures for the invariant model and the variant model, it is evident that the AIC for the invariant model (1811.18) is lower than that for the variant model (1815.56), indicating that the invariant model is more parsimonious and better fitting than the variant model. Table 5 presents the goodness-of-fit indices for both these models, together with the model comparison statistics. 
Table 5. Chi-Square Goodness-of-Fit Values, Incremental Fit Indices (NFI, IFI, TLI, CFI), Akaike Information Criterion (AIC), and Model Comparison (Model 3)

\begin{tabular}{lcccccccc}
\hline Model & $\begin{array}{c}\chi^{2} \\
(N=998)\end{array}$ & $d f$ & $P$ & NFI & IFI & TLI & CFI & AIC \\
\hline $\begin{array}{l}\text { Null Model } \\
\text { Model A } \\
\text { (Invariant) Model }\end{array}$ & 11593.39 & 693 & $<.001$ & 0.00 & 0.00 & 0.00 & 0.00 & 11725.39 \\
$\begin{array}{l}\text { Model B } \\
\text { (Variant) Model }\end{array}$ & 1537.18 & 622 & $<.001$ & 0.87 & 0.92 & 0.91 & 0.92 & 1811.18 \\
$\begin{array}{l}\text { Model comparison } \\
\text { Model A vs Model B }\end{array}$ & 15.62 & 10 & $<.001$ & 0.00 & 0.00 & 0.00 & 0.00 & 4.38 \\
\hline
\end{tabular}

\section{Standardized regression paths for the three types of procrastinators}

As depicted in Figure 3, the achievement goals of performance-approach goals and performance-avoidance goals are significantly and directly related to the participants reported level of academic achievement. Specifically, for all three groups of non-procrastinators, active procrastinators, and passive procrastinators, (1) the more they adopted performance-approach goals, the higher their level of academic achievement $(\beta=0.46, \beta=0.37, \beta=0.41$ respectively), and (2) the more they adopted performance-avoidance goals, the lower their level of academic achievement ( $\beta=$ $0.44, \beta=-0.36, \beta=-0.40$ respectively). The results showed no significant relationships between the model's exogenous variables of academic self-efficacy, mastery-approach goals, and masteryavoidance goals with the criterion variable of academic achievement $(p>.05)$.

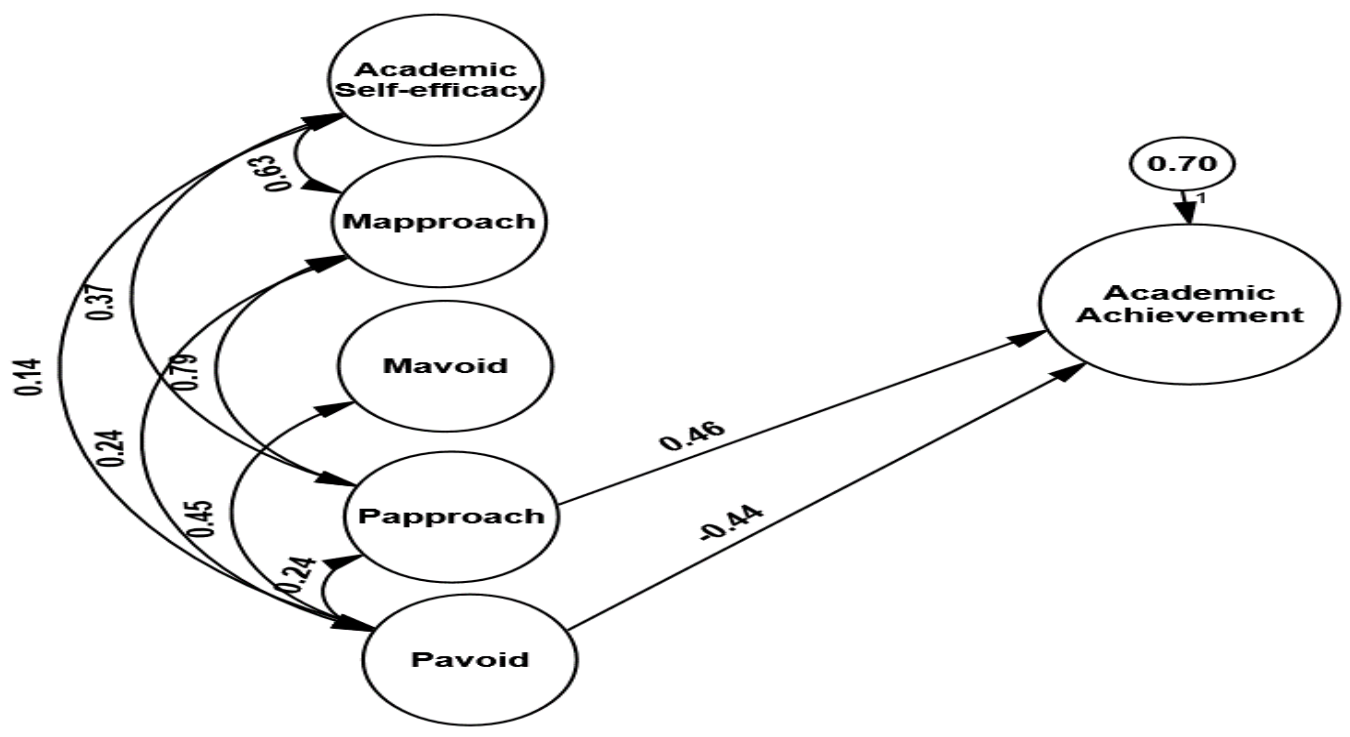




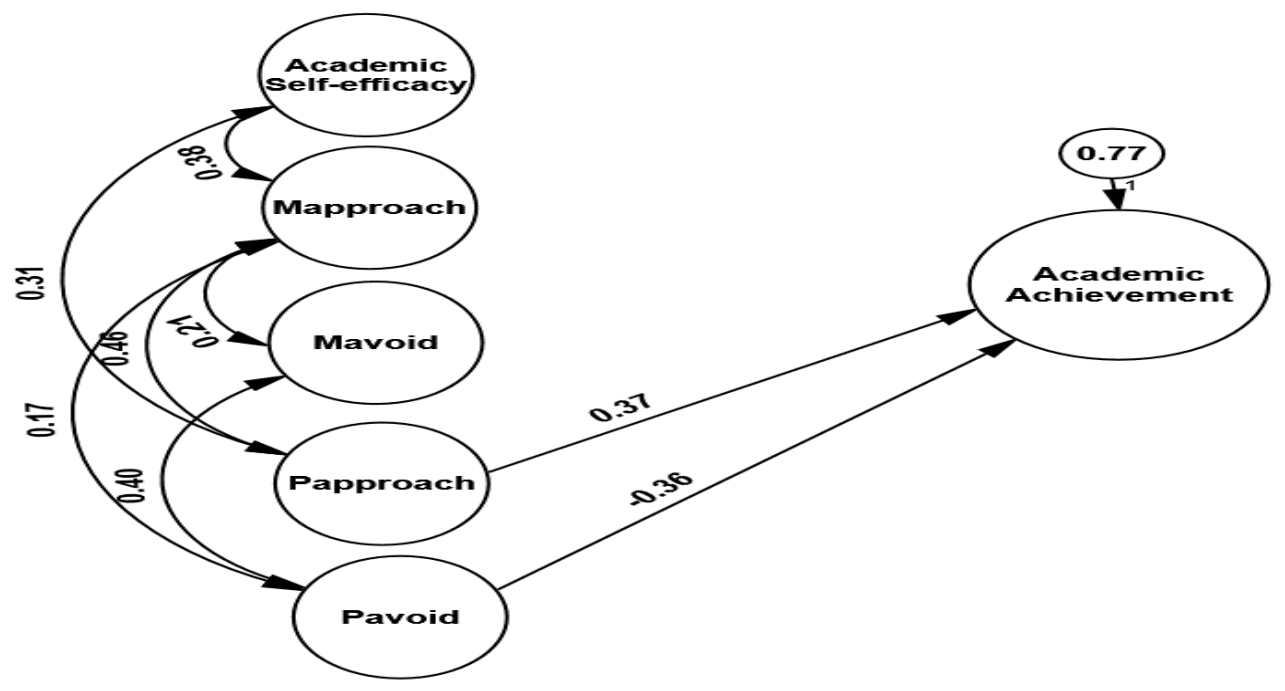

Active Procrastination

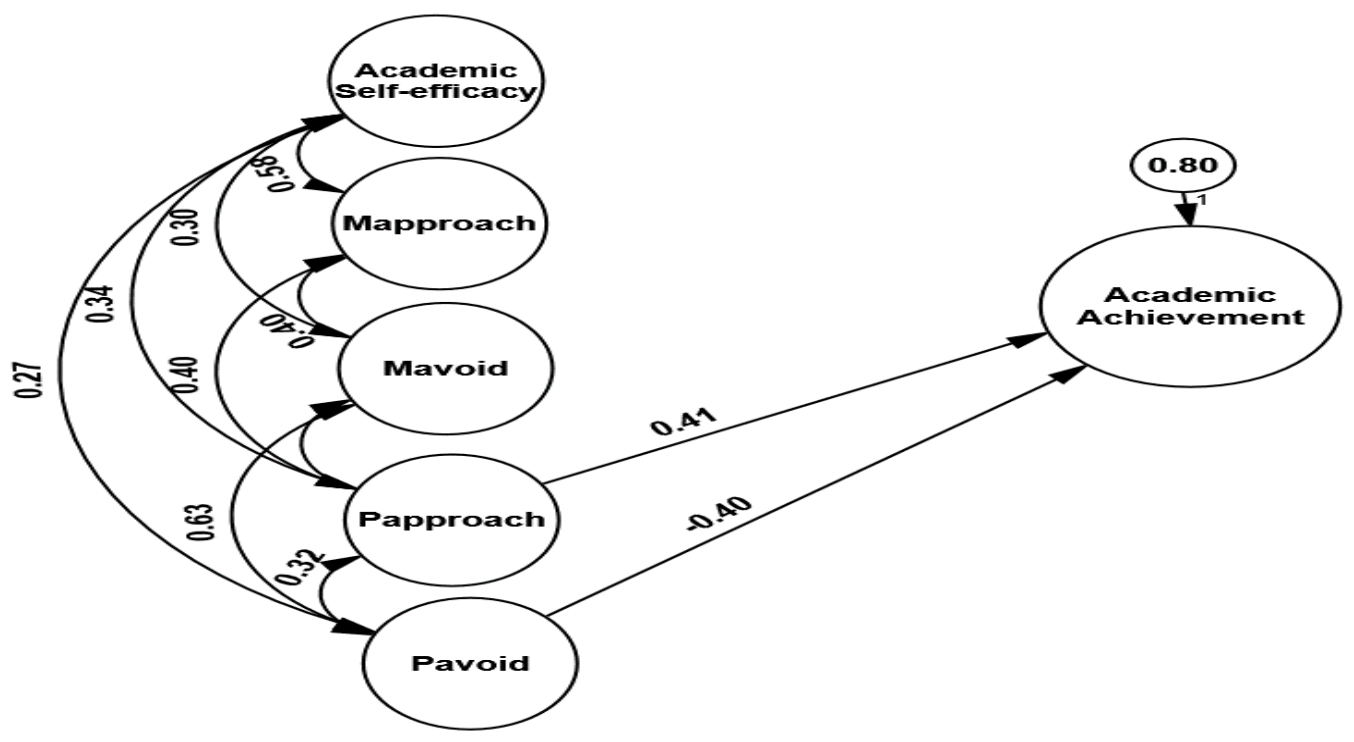

Passive Procrastination

Figure 3. Academic achievement path model (Model 3) for the three types of procrastinators together with the model's significant path coefficients 
Table 6. Summary of the Significant Path Coefficients Across the Three Types of Procrastinators (Model 3)

\begin{tabular}{lccc}
\hline \multirow{2}{*}{ Parameter } & Path Coefficients & \\
\cline { 2 - 4 } & Non & Active & Passive \\
& Procrastinators & Procrastinators & Procrastinators \\
\hline Papproach $\rightarrow$ Academic achievement & 0.46 & 0.37 & 0.41 \\
Pavoid $\rightarrow$ Academic achievement & -0.44 & -0.36 & -0.40 \\
\hline
\end{tabular}

From Table 6 it can be seen that the pattern of relationship between the achievement goals of performance-approach goals and performance-avoidance goals with academic achievement is similar for all three groups of procrastinators. Specifically, for non-procrastinators, active procrastinators, and passive procrastinators, their adoption of performance-approach goals is associated with higher academic achievement ( $\beta=0.46, \beta=0.37, \beta=0.41$ respectively). Alternatively, their adoption of performance-avoidance goals is associated with lower academic achievement $(\beta=-$ $0.44, \beta=-0.36, \beta=-0.40$ respectively).

\section{Discussion and Conclusions}

This study focused on how students who procrastinate (versus those who do not) differ in the ways their academic-self-efficacy and achievement goals impact on their academic achievement. The two different configuration of Model 1 (achievement goals $\rightarrow$ academic self-efficacy $\rightarrow$ academic achievement) based on the achievement goals theory integrated factors between achievement goal and academic self-efficacy. Two integrated factors will enhance students when dealing with difficult tasks simultaneously and Model 3 (academic self-efficacy, achievement goals $\rightarrow$ academic achievement) based on social cognitive theory separated factors of achievement goals and academic selfefficacy. This theory stated that the two motivational factors could enrich persons' potential to achieve ultimate goal independently. Therefore, the two different configuration models were employed to evaluate their consistency across the three groups of procrastinators (non-procrastinators, active-procrastinators, and passive procrastinators). The result found that non-procrastinators and active procrastinators presenting a direct relationship between achievement goals and academic achievement while passive procrastinators showing an indirect relationship between achievement goals and academic achievement which is mediated by academic self-efficacy. More illustrated details were presented as follows: 


\section{Roles of integration of achievement goal and self-efficacy towards non-procrastinator and procras-} tinator groups

When comparing Model 1 and Model 3 on the relationship among achievement goal, academic self-efficacy, and academic achievement across the three groups of procrastinators, the results found that Model 1 showed a higher number of significant relationships than Model 3. One possibility to explain may be while we have to pursue task, particularly, the painstaking tasks and long-term commitment like study in university, we have to integrate self-efficacy, motivational belief as well as have a concrete clear process in order to uphold students' emotion and motivation to complete task successfully (Hensley, 2014, Krause \& Freund, 2016, Balkis \& Duru, 2016). Improving attitudes particularly on reduced quantitative anxiety and increased quantitative self-efficacy showed significantly improvement of academic achievement in a long-term period as well (Harlow, Burholder, \& Morrow, 2002). Some psychological motivation factors e.g., self-regulation learning, exintric and intrinc motivation, and task value may need to testify to identify the different motivational beliefs among nonprocrastinator, active procrastinator, and passive procrastinator ( $\mathrm{Li}, 2012)$. The following information expounds the pattern of relationships of the academic achievement model across all three types of procrastinators, with a focus on Model 1.

Non-procrastinators and active procrastinators' achievement goals reported a direct and significant association with academic achievement whereas passive procrastinators' achievement goals reported both direct and indirect relationships with academic achievement. An explanation for this could be that both groups, non-procrastinators and active procrastinators were confident in their ability to work on challenging tasks and to meet deadlines (Choi \& Moran, 2005). Moreover, previous studies have confirmed to separate the active and passive procrastination due to active procrastinators demonstrated positive outcome than passive procrastinator (Danya, Shirley, \& Lindt, 2011, Seo, 2012, \& Hensley, 2014). On the contrary, passive procrastinators tended to postpone tasks in order to protect vulnerable self-worth or lack of self-confidence when having to handle tasks in which they have less skill (Holmes, 2000, Seo, 2012, \& Hensley, 2014). Due to the underlying negative self-worth of the passive procrastinator, academic self-efficacy may mediate the relationship of achievement goal and academic achievement. Therefore, it is quite justifiable to find support for the indirect relationships that occurred, particularly in the case of the passive procrastinator. The supporting example is that passive procrastinators endorse their performance-avoidance goals which were drawn from fear of failure were positively related to academic self-efficacy ( $\beta=0.56$ ), resulting in higher level of academic achievement $(\beta=0.64)$. Although this particular result was contradictory to the outcome of large body of aforementioned researches, it is similar to the research result of Bong (2001) who found a positive relationship between performance-avoidance goal and task value. Bong explained that students who held performance-avoidance goals and felt more self- 
efficacious tended to make an effort to improve their competence and tried very hard to avoid looking incapable.

\section{Limitation}

There are procedural limitations that should be noted and which suggest caution when interpreting the present findings. First, this research involved only sophomore students studying in universities located in Songkhla Province; therefore, the results should be cautious about generalizing to other population. Second, most of the participants studied in the Business Administration Department, where their course requirements could have engaged them in a more superficial process relating to the course material. Regarding the pattern of learning style, this may induce students to adopt the performance goal rather than the mastery goal; therefore, comparing students studying in other departments who are required to learn material at a deeper level may address this limitation. Lastly, the percentage of endogenous variables explained by the models was not that high (26\% for Model 1, 28\% for Model 2, and 27\% for Model 3). It can be inferred that there were other factors that influenced academic achievement which were not included in the scope of this research.

\section{Conclusions and Implications}

First, this research found significant outcomes related to academic achievement of the separation of a novel domain of achievement goal: mastery avoidance goal and the division of procrastination to be passive and active dichotomy. Therefore, it is important for researchers, educators, and psychologists to consider that procrastinators could be separated into two types in order to enhance treatment programmes or conduct further research more effectively. Second, multifaceted constructs (cognition, affect, and behavior) are needed to integrate when handling with the difficult tasks, particularly passive procrastinators who are doubtful about their ability and overwhelmed with fear of failure while tangling with difficult tasks. This could imply that academic self-efficacy may motivate passive procrastinators who are trapped in an approach-avoidance conflict (Miller \& Rollnick, 2002) to achieve their academic goals. Researchers, educators, or psychologists who wish to further study this area of an intervention programme may apply the integrated factors (academic selfefficacy, achievement goal) to help the individuals deal with their procrastination, change and encourage their behaviors to pursue their academic goal durably. Lastly, generally the study found that almost all students who endorsed achievement goals based on a fear of failure, such as the mastery avoidance goal, performance approach goal, and performance avoidance goals, were significantly related to academic achievement. It is a major challenge for Asians as well as Thai students who are grounded in their need to avoid failure in order to gain the acceptance of their significant others; 
therefore, it is important for the government, schools, and parents not to neglect 'the right' or privilege of students to learn with happiness and in a joyful environment.

\section{References}

Akaike, H. (1987). Factor analysis and AIC. Psychometrika 52, 317-332. https://doi.org/10.1007/BF02294359.

Ames, C. (1992). Classroom: Goals, structures, and student motivation. Journal of Educational Psychology, 84, 261-271. doi: 10.1037/0022-0663.84.3.261

Arbuckle, J.L., \& Wothke, W. (1999). AMOS 4.0 User's Guide, Chicago: SmallWaters Corporation.

Balkis, M., \& Duru, E. (2016). Procrastination, self-regulation failure, academic life satisfaction, and affective well-being: Underregulation or misregulatiion form. European Journal of Education, 31, 439-459. doi: 10.1007/s10212-015-0266-5.

Bandura, A. (1986). Social foundations of thought and action: A social cognitive theory. Englewood Cliffs, NJ: Prentice Hall.

Bjornebekk, G., Diseth, A., Ulriksen, R. (2013). Achievement motives, self-efficacy, achievement goals, and academic achievement at multiple stages of education: A longitudinal analysis. Psychological Reports, 112, 771-787. doi: 10.2466/14.09.PR0.112.3

Bong, M. (2001). Between- and within-domain relations of academic motivation among middle and high school students: Self-efficacy, task-value, and achievement goals. Journal of Educational Psychology, 9, 23-34. doi: 10.I037//0022-0663.93.1.23.

Bong, M. (2008). Effect of parent-child relationships and classroom goal structures on motivation, help-seeking avoidance, and cheating. The Journal of Experimental Education, 76, 191217. doi: 10.3200/JEXE.76.2.191-217.

Browne, M. W., \& Cudeck, R. (1993). Alternative ways of assessing model fit. In K. A. Bollen \& J. S. Long (Eds.), Testing structural equation models (pp. 445-455).

Choi, J. N., \& Moran, S. V. (2009). Why not procrastination? Development and validation of a new active procrastination scale. The Journal of Social Psychology, 149, 195-211. doi:10.3200/SOCP.149.2.195-212.

Chu, A. H. C., \& Choi, J. N. (2005). Rethinking procrastination: Positive effects of “active" procrastination behavior on attitudes and performance. The Journal of Social Psychology, 145, 245-265. doi:10.3200/SOCP.145.3.245-264.

Corkin, D. M., Yu, S. L., \& Lindt S. F. (2011). Comparing active delay and procrastination from a self-regulated learning perspective. Learning and Individual Differences, 11, 602-606. doi:10.1016/j.lindif.2011.07.005. 
Elliot, A. J. (1999). Approach and avoidance motivation and achievement goals. Educational Psychologist, 34, 169-189. doi.org/10.1207/s15326985ep3403_3.

Elliot, A. J., \& Murayama, K. (2008). On the measurement of achievement goals: Critique, illustration, and application. Journal of Educational Psychology, 100, 613-628. doi.org/10.1037/0022-0663.100.3.613.

Harlow, L.L., Burholder, G.J. and Morrow, J.A. (2002). Evaluating attitudes, skill, and performance in a learning-enhanced quantitative methods course: A structural modeling approach. Structural Equation Modeling-A multidisciplinary Journal, 9, 413-430. doi: 10.1207/S15328007SEM0903_6.

Holmes, R. (2000). The effect of task structure and task order on subjective distress and dilatory behavior in academic procrastinators (Unpublished doctoral dissertation). Hofstra University. Dissertation Abstracts International, 62, 3803.

Hensley, C. L. (2014). Reconsidering active procrastination: Relations to motivation and achievement in college anatomy. Learning and Individual Differences, 36, 157-164. doi: 10.1016/j.lindif.2014.10.012.

Hulleman, C., Scheager, S., Bodmann, S. \& Harackiewicz, J. (2010). A meta-analytic review of achievement goal measures: different labels for the same constructs or different constructs with similar labels? Psychological Bulletin. 2010, 136, 422-449. doi:10.1037/a0018947.

Kizilgunes, B., Tekkaya, C., \& Sungur, S. (2009). Modeling the relations among students' epistemological beliefs, motivation, learning approach, and achievement. The Journal of Educational Research, 102, 243-255. doi:10.3200/JOER.102.4.243-256.

Krause, K. \& Freund, A. (2016). It's in the means: Process focus helps against procrastination in the academic context. Motivation and Emotion, 40, 422-437. doi: 10.1007/s11031-016-9541-2.

Li, C. (2012). Examining 'active' procrastination from a self-regulated learning perspective. Journal Educational Psychology An International Journal of Experimental Educational Psychology, 32, 515-545. https://doi.org/10.1080/01443410.2012.663722.

Mendelson, N. (2007). The functional mediation of flow between achievement anxiety, academic procrastination, and academic performance (Unpublished doctoral dissertation). Fordham University, New York, United States.

Miller, R. W., \& Rollnick, S. (2002). Motivation interviewing: Preparing people for change. ( $2^{\text {nd }}$ ed.). London: The Guilford.

Ngamsiri, R. (1997). An analysis of causal relationship on variables influencing test anxiety of Mathayom Suksa Six students, Bangkok Metropolis (Unpublished doctoral dissertation). Chulalongkorn University, Bangkok, Thailand. 
Rice, K.G., Richardson, C.M.E., \& Clark, D. (2012). Perfectionism, procrastination, and psychological distress. Journal of Counseling Psychology, 59, 288-302. doi: 10.1037/a0026643.

Seo, H, E. (2012). Cramming, active procrastination, and academic achievement. Social Behavior and Personality an International Journal, 40, 1333-1340. doi: 10.2224/sbp.2012.40.8.1333.

Schouwenburg, H. C. (1992). Procrastinations and fear of failure: An exploration of reasons for procrastination. European Journal of Personality, 6, 225-236. doi:10.1002/per.2410060305.

Schraw, G.,Wadkins, T., \& Olafson, L. (2007). Doing the things we do: A grounded theory of academic procrastination. Journal of Educational Psychology, 99, 12-25. doi: 10.1037/00220663.99.1.12.

Schunk, D.H., \& Pajares, F. (2005). Competence perceptions and academic functioning. In A.J. Elliot, \& C. Carol, (Eds.), Handbook of competence and motivation (pp.85-104). NewYork: Guilford Press.

Tice, D.M., \& Baumeister, R. F. (1997). Longitudinal study of procrastination, performance, stress, and health: The costs and benefits of dawdling. Psychological Science, 8, 454-458.

Wolters, C. A. (2003). Understanding procrastination from a self-regulated learning perspective. Journal of Educational Psychology, 95, 179-187. doi: 10.1037/0022-0663.95.1.179.

Wolters, C. A. (2004). Advancing achievement goal theory: Using goal structures and goal orientations to predict students' motivation, cognition, and achievement. Journal of Educational Psychology, 96, 236-250. doi: 10.1037/0022-0663.96.2.236.

Wigfield, A. (1994). Expectancy-value theory of achievement motivation: A developmental perspective. Educational Psychologist, 6, 49-78. doi: 10.1007/BF02209024.

Wigfield, A., \& Eccles, J. S. (2000). Expectancy-value theory of motivation. Contemporary Educational Psychology, 25, 68-81. doi:10.1006/ceps.1999.1015. 